\title{
Spectral analysis of copper zinc sulphide ternary thin film grown by solution growth technique
}

\author{
Uhuegbu, C. C. and E.B. Babatunde \\ Department of Physics, Covenant University Ota, Ogun State Nigeria \\ E-mail Address: cuhuegbu@yahoo.co.uk
}

\begin{abstract}
Copper zinc sulphide ternary thin film has been grown and characterized by spectrophotometry. The optical properties considered revealed high absorbance and reflectance but low transmittance in the UV; low values of absorbance and reflectance accompanied but high transmittance in the VIS - IR regions. The possible applications were mentioned.
\end{abstract}

Keywords: Solution growth technique (SGT), absorbance, transmittance, reflectance and copper zinc sulphide thin film.

\section{INTRODUCTION}

Interest on the preparation and study of physical properties of ternary chalcogenide compounds for their possible applications in solar cells, light emitting diodes and non-linear optical devices [1] has increased in recent years.

Ternary compounds are found to be promising material for optoelectronic device applications such as green light emitting devices and are suggested to be possible material for window layer of solar cells [2]. Some of them have been investigated for specific applications such as super-ionic conducting materials [3]. Some of them are studied for efficient solar energy conversion [4, 5, 6-15]. Ternary thin films deposition had been reported using advanced technologies, but the less expensive and simple technique is the solution growth technique (SGT) [1626].

This paper reports the investigation of spectral properties of copper zinc sulphide thin films which were deposited using solution growth technique. The spectral properties investigated include absorbance $(A)$, transmittance $(T)$ and reflectance $(R)$. These properties were determined based upon equations found in literatures [26-38].

\section{EXPERIMENTATION AND MATERIALS}

The chemical deposition of copper zinc sulphide ternary thin film onto the glass substrates (slides) was carried out by using a mixture of $1 \mathrm{M}$ copper chloride, $0.1 \mathrm{M}$ ethylenediaminetetraacete (EDTA), $0.1 \mathrm{M}$ zinc nitrate, $7.4 \mathrm{M}$ triethanolamine (TEA), $14 \mathrm{M}$ ammonia, $1 \mathrm{M}$ thiourea, distilled water, microscopic glass slides and beakers.
The chemical bath deposition technique was used to prepare the $\mathrm{Cu}_{2} \mathrm{ZnS}_{2}$ ternary thin films on glass substrate (slide) which had been previously degreased in concentrated nitric acid for 48 hours, cleaned in cold water with detergent, rinsed with distilled water and dried in air. The degreased cleaned surface provide nucleation centre for growth of the film, hence yielding highly adhesive and uniformly deposited film.

The mixture was thoroughly stirred with a glass rod before the glass slide was vertically introduced into the beaker. The dip time of about 20-48 hours at $\mathrm{pH}$ between 9 and 11 was observed for the deposition process which took place at room temperature. The grown samples were removed from the reaction baths, rinsed with distilled water and allowed to dry. They were then annealed at $420 \mathrm{~K}$ for 1 hour to obtain adherent transparent thin films.

During deposition, cations and anions in the deposition solution reacted to become neutral atoms which either precipitated spontaneously or vary slowly. Fast precipitation is an indication that thin films could not be formed on the substrate immersed in the solution.

However, with the addition of $\mathrm{NH}_{3}$ and EDTA, the reaction slowed down for thin film of neutral atom to be formed on the substrate. Sulphide ions were released by hydrolysis of thiourea. By the process of ion-by-ion exchange, $\mathrm{Cu}_{2} \mathrm{ZnS}_{2}$ was deposited on the glass substrate in the form of transparent, uniform and adherent ternary thin film.

The step wise reactions involved in the complex ion formation and film deposition processes for $\mathrm{Cu}_{2} \mathrm{ZnS}_{2}$ are: 
Am. J. Sci. Ind. Res., 2010, 1(3): 397-400

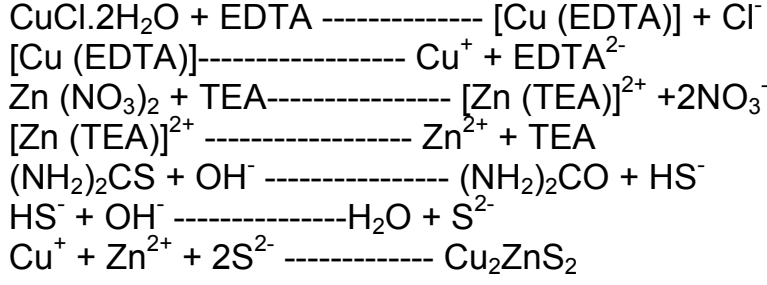

\section{RESULT AND DISCUSSION}

The graphs of spectral absorbance, transmittance and reflectance versus wavelengths are presented in figures 1, 2 and 3 respectively.

Absorbance increased from a value of 0.20 at 230 $\mathrm{nm}$ to various maximum values of 0.44 at $280 \mathrm{~nm}$ for CuZnS3, 0.52 at $280 \mathrm{~nm}$ for CuZnS1 and 0.72 at 280 $\mathrm{nm}$ for CuZnS2 and decreased rather sharply for CuZnS2 to a minimum value of 0.2 at $590 \mathrm{~nm}$ and 0.12 at $740 \mathrm{~nm}$ for CuZnS1 and CuZnS3. For CuZnS2, it increased with wavelength.

Transmittance decreased from a value of about $59 \%$ at $240 \mathrm{~nm}$ to various minimum values of $36 \%$ at 280 for CuZnS3, $30 \%$ at $280 \mathrm{~nm}$ for CuZnS1 and $20 \%$ at $280 \mathrm{~nm}$ for CuZnS2 before increasing to a maximum value of $62 \%$ at $580 \mathrm{~nm}$ and decreased gently with wavelength for CuZnS2 while for CuZnS1 and CuZnS3 increased with wavelength.

Reflectance for CuZnS1 increased from a value of 7 $\%$ at $200 \mathrm{~nm}$ to a maximum value of $19 \%$ at $260 \mathrm{~nm}$ and thereafter increased to a maximum value of $20 \%$ at $360 \mathrm{~nm}$ before decreasing to $13 \%$ at $760 \mathrm{~nm}$. For CuZnS2, reflectance decreased from $20.5 \%$ at 240 $\mathrm{nm}$ to a minimum value of $10 \%$ at $280 \mathrm{~nm}$ before increasing to $20.5 \%$ at $420 \mathrm{~nm}$. Reflectance for CuZnS3 increased from a value of $9 \%$ at $200 \mathrm{~nm}$ to a maximum value of $20.5 \%$ at $260 \mathrm{~nm}$ and then decreased to $19.5 \%$ at $300 \mathrm{~nm}$. Thereafter it increased to another maximum value of $20.5 \%$ at $340 \mathrm{~nm}$ before decreasing to $12 \%$ at $720 \mathrm{~nm}$.

These results indicate that the films have high absorbance at UV wavelength $(0.2 \mu \mathrm{m} \leq \lambda \geq 0.4 \mu \mathrm{m})$ and low absorbance at visible and infrared (IR) wavelengths $(0.4 \mu \mathrm{m} \leq \lambda \geq 4 \mu \mathrm{m})$ as shown in figure.1. While in figure.2, the transmittance is high at the visible and infrared wavelengths and low at UV wavelength. In figure.3, two of the films indicate high reflectance in the UV wavelength and low reflectance in the visible and infrared wavelengths, while the third shows the opposite.

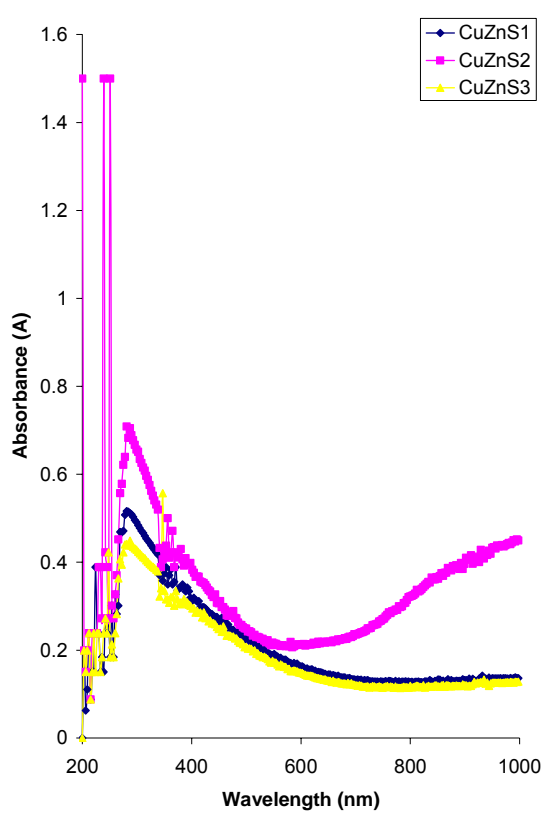

Figure 1 : Absorbance $(A)$ as function of wavelength $(\lambda)$ for CuZnS Thin Film

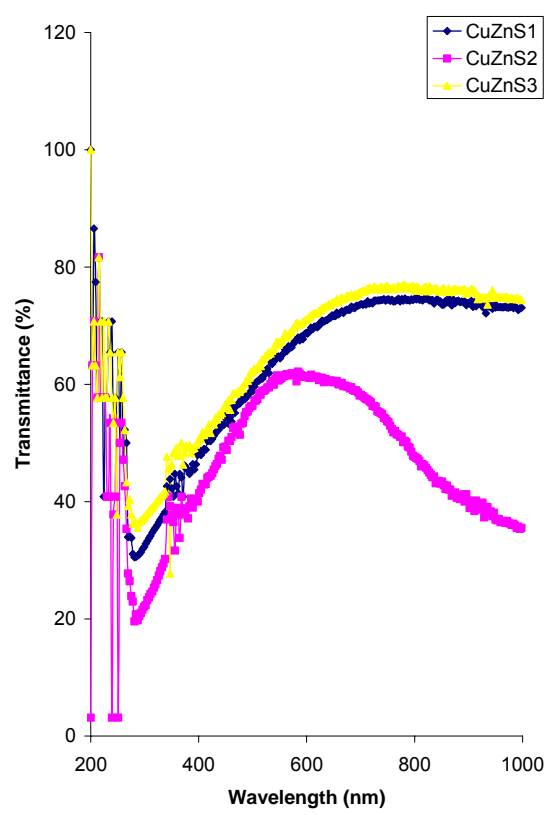

Figure $2:$ Transmittance $(T)$ as function of wavelength $(\lambda)$ for CuZns Thin Film 


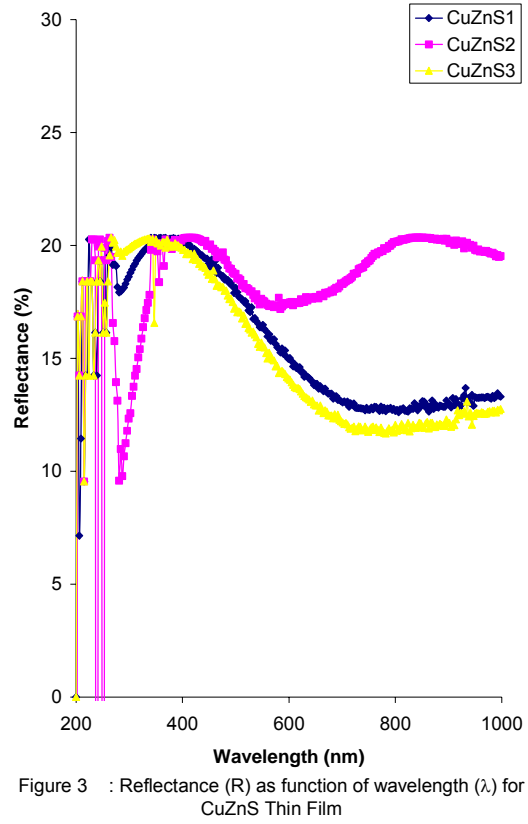

The film has high transmittance at visible but absorb highly in the UV and near infrared wavelengths. The shape of the spectral curve for this film shows that they can only allow visible radiation to be transmitted through the glazing system into the building if these films are used in coating the glazing. These types of films are designated visibly transparent film (VTF) in this work. Also because the film can be used to transmit solar radiation $(0.3$ to about $3.0 \mu \mathrm{m})$ into building, the films can be called solar transmitting films (STF) such films can also be used to anti-reflect solar radiation falling on and passing through solar collector glazing onto absorber plates in photothermal solar energy devices. This type of action would reduce the reflection of solar energy at the airglass interface thereby causing high transmission of solar radiation into the device. These types of films are designated as solar anti reflection films (SARF). The variations observed from the three graphs may be due to variation in concentrations and impurities from the environment the experiment is carried out.

\section{CONCLUSION:}

New ternary thin films of copper zinc sulphide using solution growth technique have been grown and characterized. It can be said that the ternary thin films have the properties of screening off UV portion of the electromagnetic radiation by absorbing and reflecting and admittance of the visible and infrared radiation by transmission.
These properties confirm the films good materials for coating poultry buildings, eye glasses coating, solar thermal conversion, anti-reflection coating and solar cells fabrication.

\section{REFERENCES}

[1] K.L Chopra, and S.R. Das, Thin Solar cells, (Plenum press. New York) (1983)

[2] T. Roseberg, S. kuan and H.J. Hovel, Physics Today 33(5) (May 1980), $41 \mathrm{~J} \mathrm{Y}$

[3] K. J. Choi, J. B. Kim Yoo and D. Kim, Solar energy 64 (1-3), (1998), 41

[4] P. K. Nair, M.T.S. Nair, A. Fernandez and M. Ocampo, J. Phys. D Appl. Phys. 22, (1989), 829

[5] P.K Nair and M.T.S. Nair, Semicond. Sci. Technol. 4, (1989), 807

[6] P. K. Nair and M.T.S. Nair, Semicond. Sci. Technol. 7, (1992), 239

[7] P. K. Nair, M. Ocampo, A. Fernandez and M.T.S. Nair, Sol Ener. Mater. 20, (1990), 235

[8] P. K. Nair and M.T.S. Nair, Sol. Ener. Mater 15, (1987) 431

[9] M. T. S. Nair and P.K. Nair, Semicond. Sci. Technol. 4, (1989), 191

[10] P. K. Nair and M.T.S. Nair, Solar Cells, 22 (1987), 102

[11] I. C. Ndukwe, Sol. Ener.Mater. Sol.Cells 40 (1996), 123

[12] R. Ortega-Borges and D. Lincot, J. Electrochem.Soc., 140 (1993), 3464

[13] G. K. Padam and S.U.M. Rao, Sol.Ener.Mater. 13 (1986), 297

[14] P. S. Pramanik, R. N. Bhattacharya and P.K. Basu, Thin Solid Films, 149 (1987), 181

[15] P. J. Sabestian and H. Hu, Adv. Mater. Opt. Electron, 4 (1994), 407

[16] K. L. Chopra, R. C. Kainthla, D. K. Pandya and A.D. Thakoor, Physics of thin films, vol. 12 (1982) Academic press New York

[17] I. Kaur, D. K. Pandya and K. L. Chopra, J. Electrochem.Soc. 127, (1980), 943

[18] F. I. Ezema and C.E. Okeke, Nig J. Phys. 14(2), (2002), 48

[19] F. I. Ezema, and C.E. Okeke, Nig. J. Solar Ener. 14 (2003), 68

[20] F. I. Ezema and C. E. Okeke, Academic Open Internet Journal 
http://www.acadjournal.com/2003/v9/part2/p4/chemical bath deposition.pdf

[21] F. I. Ezema and C.E. Okeke, Greenwich Journal of Science and Technology, 3(2), (2003), 90

[22] F. I. Ezema and P.U. Asogwa, Pacific Journal of Science and Technology 5(1), (2004), 33

[23] F. I. Ezema, Journal of the University of chemical Technology and metallurgy 39 (2), (2004), 225

[24] F. I. Ezema, Open internet Journal http://www.acadjournal.com/2004/vii/part2/p1/index.htm

[25] V. S. Karande, S.H. Mane, V.B. Pujari and L.P. Deshmukh, Turk. J.Phys. 27, (2003), 559

[26] D. S. Sutrave, G.S. Shakane, V.B. Patil and L.P. Deshmukh, Turk. J. Phys. 24 (2000),63

[27] V. B. Pujari, V. B. Gaikward, E.U. Masumdar, P.D. More and L.P. Deshmukh, Turk. J. Phys. 26, (2002) 407

[28] V. Estrella, M.T.S. Nair and P.K. Nair, Semicond. Sci. Technol., 18 (2003), 190

[29] A. Numez- Rodriguez, M.T.S. Nair and P.K. Nair, Mater. Res. Symp. Proc.,730, (2002), v5.14.1
[30] Y. Rodriguez-Lazcano, L.Guerrero, O. GomezDaza, M.T.S. Nair and P.K.Nair, Superficies y vacio 9 (1999), 100

[31] Y. Rodriguez-Lazcano, M.T.S. Nair and P.K. Nair, J. Crystal Growth, 23(3), (2001), 399

[32] P. K. Nair, L. Huang, M.T.S. Nair, H. Hu, E.A. Meyers and R.A. Zingaro, J. Mater. Res. 12 (3), (1997), 651

[33] N. A. Lange, Lange's Handbook of chemistry, $14^{\text {th }}$ edn, McGraw-Hill Book Co., New York, 1992

[34] I. M. Tsidilkovsk, Band structure of semiconductors, Pergamon Press Oxford (1982)

[35] J. I. Pankove, Optical Processes in semiconductors Prentice Hall New York (1971)

[36] M. Janai, D. D. Alfred, D.C. Booth and B.O. Seraphin, Sol. Ener. Mater. 1 (1979), 11

[37] M. Theye, optical Properties of thin films, (edited by K.L. Chopra and L.K. Malhota), thin film technology and applications (Tata McGraw-Hill, New Delhi), (1985)

[38] F. I. Ezema, Journal of University of Science and Technology 23(2), (2003), 